\title{
Physicians and climate change policy: We are powerful agents of change
}

\author{
Kirsten Patrick MBBCh DA
}

$\mathrm{I}$ n December 2014, the World Medical Association (WMA) issued a statement ${ }^{1}$ urging governments to commit to an ambitious and binding climate agreement when the Sustainable Innovation Forum reconvenes in Paris in December 2015. The WMA also urged that the health sector be "fully integrated" in the current global debate and action on climate change. But what action can physicians take to influence meaningful global action on climate change?

The latest Intergovernmental Panel on Climate Change report, released in 2014, outlined more clearly and with greater certainty than ever before how both climate change and pollution from the combustion of fossil fuels have killed thousands of people and will threaten the lives of many more. ${ }^{2}$

In 2010, a position statement from the Canadian Medical Association $^{3}$ called for physicians to take action, but it focused largely on developing strategies to deal with the impending effects of climate change on health and health systems. In 2013, a CMAJ editorial ${ }^{4}$ discussed the role of physicians on the front line of climate change and examined how they can make a difference at the political, professional and individual levels. These recommendations remain pertinent.

Prompt action on reducing fossil fuel emissions in the near term, to prevent irredeemable downstream effects, is just as important as responding to current and imminent threats. An emergency medicine physician based in Yellowknife summed it up well when she likened the relatively small window for action to the urgency following a myocardial infarction or the onset of sepsis. "We either get the job done in the next decade or so or we prepare for palliative care."5

Yet achieving international binding agreements seems to be happening at a slower pace than that of receding glaciers. When world leaders convene, issues related to saving the world from economic collapse, terrorist threats and oil crises seem to come before those related to saving the world from the threat of climate change. However, things are changing at the macro-economic level. The World Bank has made strides in coordinating international efforts to develop renewable energy, develop globally networked carbon markets and "enhance the flow of finance toward the ongoing effort to limit global warming." 0 One can perhaps see the influence of the current president of the World Bank, who is a physician and social anthropologist, in these recent actions.

Humans are bad at envisioning or appreciating the longterm consequences of behaviour. Behavioural scientists call the phenomenon "delayed reward discounting." In short, we need salience now. In developed countries such as Canada, many of the adverse effects of climate change will only affect future generations. Although we may believe the science and many of us may support our government in making binding agreements to reduce carbon emissions, changing our personal behaviours may be costly, inconvenient and difficult. How do we galvanize to combat global warming?

Health promotion campaigns are most effective when delivered on multiple levels at once, combining information on the health benefits of a behaviour change with modelling of the behaviour, reduced barriers to its adoption, a good system of social support for those who adopt it, and person-toperson promotional initiatives and media campaigns. ${ }^{7}$

We need such a multipronged campaign to drive real action on climate change. Physicians are agents for change at all levels, and we can do more to bring climate change to the forefront of people's consciousness. With our unique comprehension of stages of change and skill at intervening to help individuals make lifestyle changes at whichever stage they may find themselves, we can make a big impact.

We have managed to effect social change regarding smoking despite the power of industry, and we are beginning to turn the tide against the anti-vaccine lobby. Our approach to overcoming the stalling tactics of climate-change deniers should be no different. A few years ago, it was unusual to ask patients about how much physical activity they engaged in or how much sitting their job demanded. Now, we counsel about the risks of being underactive and write exercise prescriptions. It is time for physicians to talk about the effects of climate change routinely in daily practice. We should not forget that we are respected, influential advocates.

\section{References}

1. WMA calls for urgent action on climate change to protect health. Ferney-Voltaire, (France): World Medical Association; 2014. Available: www.wma.net/en/40news /20archives/2014/2014 39/index.html (accessed 2015 Feb. 2).

2. Climate change 2014: synthesis report: summary for policymakers. Geneva: Intergovernmental Panel on Climate Change; 2014. Available: http://ipcc.ch/pdf/assessment -report/ar5/syr/SYR AR5 SPMcorr1.pdf (accessed 2015 Feb. 2).

3. Climate change and human health [policy]. Ottawa: Canadian Medical Association; 2010. Available: www.cma.ca/Assets/assets-library/document/en/advocacy/PD10 -07-e.pdf (accessed 2015 Feb. 2).

4. Sibbald B. Physicians' roles on the front line of climate change. CMAJ 2013;185:195.

5. Howard C. Climate change is a health issue [letter]. CMAJ 2013;185:587.

6. Globally networked carbon markets. Washington (DC): World Bank; 2014. Available: www.worldbank.org/en/topic/climatechange/brief/globally-networked-carbon-markets (accessed 2015 Feb. 2).

7. Health. In: World development report 2015. Washington (DC): World Bank; 2015: 146-58. Available: www.worldbank.org/content/dam/Worldbank/Publications/WDR /WDR\%202015/Chapter-8.pdf (accessed 2015 Feb. 2).

Competing interests: See www.cmaj.ca/site/misc/cmaj_staff.xhtml

Affiliation: Deputy Editor, CMAJ

Correspondence to: CMAJ editor,pubs@cmaj.ca

CMAJ 2015. DOI:10.1503/cmaj.150139 